UDC 657.15:657.421

JEL Classification: $\mathrm{H} 83$

DOI: https://doi.org/10.32317/2221-1055.202012022

\author{
M. A. PRODANCHUK, doctor of economic sciences, \\ associate professor (docent) \\ Yu. S. BEZDUSHNA, candidate of economic sciences, \\ senior research fellow
}

\title{
Accounting for non-current assets in budgetary institutions: problems and solutions
}

The purpose of the article is to identify problematic aspects of accounting for non-current assets and to suggest their solutions using information technology and documentation.

Research methods. The methodological basis of the study is a systematic approach to the study of the processes of reflection of non-current assets in the accounting of budgetary institutions. The epistemological method is used to clarify and deepen the meaning of the concept of "non-current assets". Analysis, synthesis, induction, deduction, abstraction, idealization and generalization, as general scientific methods of cognition, are used to develop the basic principles of the theory, methodology and organization of accounting for non-current assets. Bibliographic and bibliometric types of analysis provided identification of trends in the theory and methodology of accounting, as well as problematic aspects of noncurrent assets. The method of formalization made it possible to make suggestions on how to solve the problematic aspects of accounting for non-current assets.

Research results. Identifying of problematic aspects in the accounting for non-current assets of budgetary institutions allowed to offer options for their solution, which will deepen the informativeness of accounting and reporting data and ensure their accuracy, reliability and comparability. Improving the accounting aspects of the reflection of non-current assets will also help increase the effectiveness of internal control (including inventory), and thus their management in budgetary institutions.

Scientific novelty. Theoretical and practical provisions for accounting for non-current assets of budgetary institutions are improved. Ways to improve the accounting and internal control of non-current assets for the needs of management in budgetary institutions are proposed.

Practical significance. In order to bring the national accounting system in line with international standards and in accordance with the needs of management, it is proposed to improve the reflection in the accounting of non-current assets of budgetary institutions through the use of information technology and documentation. Refs.: 11.

Keywords: non-current assets; accounting; reporting; fixed assets; inventory; budgetary institutions; public sector.

Prodanchuk Mykhailo Andriiovych - doctor of economic sciences, associate professor (docent), leading research fellow of the department of accounting and taxation, National Scientific Centre "Institute of Agrarian Economics" (10, Heroiv Oborony St., Kyiv, 03127)

E-mail: prodanchukma@gmail.com

ORCID iD https://orcid.org/0000-0003-3504-4583

Bezdushna Yuliia Serhiivna - candidate of economic sciences, senior research fellow, head of the department of accounting and taxation, National Scientific Centre "Institute of Agrarian Economics" (10, Heroiv Oborony St., Kyiv, 03127)

E-mail: bezdushna@vipo.biz.ua

ORCID iD https://orcid.org/0000-0002-5924-0805

Scientific problem. The current stage of development of our country is characterized by the desire of society and the political elite for European integration of Ukraine not only in the political but also in the economic direction. The impact of integration processes has forced the government of our country to radically change its views on accounting in budg-

(c) M. A. Prodanchuk, Yu. S. Bezdushna, 2020 etary institutions, which, above all, affected the accounting of non-current and current tangible assets.

Any novelty takes time for practical implementation, only then can it be argued about its effectiveness and feasibility. The presence of uncertainty in the accounting processes of budgetary institutions for the accounting of non-current and current tangible assets has led to the need to analyze the peculiarities of 
their operation and provide recommendations for resolving inconsistencies to bring budget accounting to the international level.

Analysis of recent research and publications. Problems of accounting in budgetary institutions are considered in the works of famous domestic scientists M.T. Bilukha, S.F. Golov, P.T. Voronchuk, V.M. Onishchuk, L. Ya. Koretsky, A.N. Kuzminsky, S. Ya. Zubilevich, F.S. Mikhalchuk, S.V. Svirko, 0.0. Chechulina and others. In most works, budget accounting is reflected as a tool to ensure centralized management of such institutions. Foreign authors draw attention to the order of accounting in budgetary institutions according to national and international standards (Mihalcea Mihaela M., Hada Izabela D., Litan Cristina S. [9]; Paliu Popa L. [10]; Georgescu Cristina E. [8]; Ballas A., Panagiotou V., Tzovas Ch. [7]), as well as budget control (Zh. Sarkisyan [11]). However, there are problematic issues that are not sufficiently reflected in the scientific literature.

The purpose of the article is to analyze the current state of accounting support and maintenance of non-current assets in budgetary institutions, identification of problems and proposals for their solution.

Research methodology. The methodological basis of the study is a systematic approach to the study of the processes of reflection of non-current assets in the accounting of budgetary institutions. The epistemological method is used to clarify and deepen the meaning of the concept of "non-current assets". Analysis, synthesis, induction, deduction, abstraction, idealization and generalization, as general scientific methods of cognition, are used to develop the basic principles of the theory, methodology and organization of accounting for non-current assets. Bibliographic and bibliometric types of analysis provided identification of trends in the theory and methodology of accounting, as well as problematic aspects of non-current assets. The method of formalization made it possible to make suggestions on how to solve the problematic aspects of accounting for non-current assets.

Research results. Financial performance appreciated on the basis of financial statement data and often on the basis of the accounting result may be misleading, being rather the result of accounting choices rather than a true presentation of reality [9, p. 210].
In the context of the debate analysis from the last decades on the relationship between accounting and taxation, independence or dependence of the accounting rules from the tax ones and taking into consideration that the independence of the two leads to permanent and even significant differences between the accounting and tax profit, revealed that certain terms are regulated differently in accounting legislation in our country compared to fiscal one or the legislation in the economic field [10, p. 39].

It is important to what extent to which the new accounting values adopted for the evaluation of fixed assets, in view of their relation to financial statements, may serve the informational needs of all financial information users. The latter are in need of credible and relevant information, which would allow anticipating the future evolution of the entity [8, p. 607].

The accounting of non-current and current tangible assets in budgetary institutions is regulated by national regulations and accounting standards in the public sector. Noncurrent and current tangible assets are, in essence, assets held for use in the activities of a budgetary institution to meet the needs of a public sector entity. The main difference is their service life and cost. Thus, the predominant service life of current tangible assets does not exceed one year. Instead, non-current tangible assets are used in budgetary institutions for a much longer period. Despite the presence of common characteristics, approaches to their accounting support in budgetary institutions differ significantly, so the existing issues are manifested in different ways.

Currently, non-current tangible assets can be structurally divided into two components, such as fixed assets and other non-current tangible assets. In the provisions of national accounting standards in the public sector 121 "Fixed assets" fixed assets and other noncurrent tangible assets are combined in one term - "fixed assets" and give it the following interpretation: tangible assets held for use in production / activities or in the supply of goods, performance of works and provision of services to achieve the set goal and / or meet the needs of the public sector entity or lease to other persons and are used, as expected, for more than one year [4]. 
At the present stage, one of the significant criteria that affect the definition and classification of an asset as property, plant and equipment or other non-current tangible assets is its price. According to the Guidelines for the accounting of fixed assets, low-value non-current tangible assets, which are part of other non-current tangible assets, include assets up to 6000 hryvnias per unit (set) without value added tax [3].

Thus, accountants of budgetary institutions in the decision to classify an asset as a fixed asset or other non-current tangible asset are bound by the value criterion of this asset, which, in our opinion, is an imperfect approach. Moreover, the determination of the value limit is influenced by the presence or absence of value added tax. That is, in the case of the purchase of an asset, for example, peripheral equipment worth UAH 7,000.00 from an individual entrepreneur (not a value added tax payer), this asset must belong to fixed assets. Instead, the purchase of a similar asset with a similar value from a legal entity that is a value added taxpayer, causes a situation where the asset should already belong to the low-value non-current tangible assets. The presence of ambiguity in the approaches when assigning an asset to fixed assets or other non-current tangible assets leads to the lack of a unified approach, which negatively affects the construction of the budget accounting system.

The presence of the above ambiguity in the definition of non-current tangible assets negatively affects the planning process in budgetary institutions. Planning in each budgetary institution begins with the approval of the budget, in accordance with the procedure and requirements provided by the resolution of the Cabinet of Ministers of Ukraine №228 of February 28, 2002 [5].

Budget funds can be allocated to institutions only in the presence of approved estimates. The recipient uses budget funds on the basis of the plan for the use of budget funds, which contains the distribution of budget allocations approved in the budget of the relevant budget manager [2].

The budget is the main planned financial document of the budgetary institution, which for the budget period establishes the authority to receive revenues and allocate budget allocations for budget commitments and payments to perform the budget institution its functions and achieve results determined in accordance with budget allocations [1].

The estimate has the following components:

- general fund, which contains the amount of revenues from the general budget fund and the distribution of expenditures according to the full economic classification of budget expenditures for the budget institution (hereinafter - the institution) basic functions or distribution of loans from the budget according to the classification of budget lending;

- special fund, which contains the amount of revenues from the special budget fund for a specific purpose and their distribution according to the full economic classification of budget expenditures for the implementation of relevant expenditures in accordance with the law, as well as for the implementation of priority measures related to the institution granting loans from the budget in accordance with the legislation on the classification of budget lending [5].

The use of the cost method in determining the asset in the implementation of planning carries certain threats. If the budget of the budgetary institution envisages the acquisition of an asset and its classification as a fixed asset, it is impossible to take into account whether the value of this asset will include value added tax. Therefore, it is impossible to reliably plan the implementation of the budget by the budgetary institution, because it is unknown whether to include such measures in current or capital expenditures.

It is important to determine what are the factors that might influence firms' choice between the two alternative valuation models provided by IAS 16 for the valuation of fixed tangible assets subsequent to their initial recognition (i.e., cost model and the revaluation model) [7, p. 19].

The presence of a value criterion when classifying an asset as property, plant and equipment or other non-current tangible assets leads to difficulties not only in reflecting this asset in accounting, but also in planning the revenues and expenditures of the budgetary institution. In our opinion, it is possible to solve this problem in two ways. The first way involves the inclusion of value added tax in the value criterion, thus not limiting the attribution of the asset depending on the form of taxation of the supplier of inventory. The second way (which, in our opinion, is the most 
rational and expedient) is to abandon the cost criterion altogether, which will allow lowerlevel fund managers to independently determine the ownership of an asset depending on its properties and characteristics. The implementation of one of the two proposals will avoid threats in the attribution of the asset when it is registered, as well as improve the organization of revenue and expenditure planning in budgetary institutions.

There are also problems with the introduction of information technology in the field of accounting of budgetary institutions, in particular the use of accounting software products to which sanctions are applied (for example, 1 C: Enterprise). Currently, the Strategy for the Development of the Accounting System in the Public Sector until 2025 has been developed, according to which the Ministry of Finance of Ukraine implements the methodological principles of accounting, organizes and creates a single unified software product for all budget institutions. However, at this stage, the accumulation of information and preparation of tax returns manually is not possible, as it is necessary to use some software products.

At present, the heads of budgetary institutions are faced with such a reality that it would be irrational to introduce a separate software product (even those that are allowed). In order to transfer the accounting of a budgetary institution to a single software product, to improve all accounting processes, to bring the document flow of a budgetary institution to compliance with the requirements of the software - it takes at least 3 years. However, today, with the transition of budgetary institutions to a new software product, and from 2025 - to another software product, there is a gap in the automation of accounting of budgetary institutions.

Today there is no effective replacement for those software products that we cannot use and we are waiting for a unified software product for all budget institutions, which, in our opinion, is a great opportunity for the development of our national accounting system and its automation. However, if we analyze the plans for the implementation of the Accounting Development Strategy until 2025, we see that Ukrainian technologists do not have time to develop these software products. The structure of financing the development of these software products indicates that $80 \%$ of expenditures are directed through the involvement of international organizations, ie currently the automation of accounting of budgetary institutions depends entirely on financing by foreign investors. It is important that national IT companies involved in information technology do not develop and cannot implement these information products in budgetary institutions due to lack of funds. We believe that more attention should be paid to this issue, because, as practice shows, the creation of a single software product (eg, E-treasury) has a positive impact on the development of budgetary institutions. However, if the development of software products is expected by 2025-2030, it will have huge negative consequences for the reliability and accuracy of accounting in budgetary institutions.

Accounting information is characterized by accuracy and reliability, which is summarized in the financial and budgetary reporting. It is extremely important to ensure the comparison of financial and budgetary reporting indicators. Previously, before the application of new approaches to accounting, the possibility of comparing the indicators of budget and financial reporting was used, however, starting from 2017, such an opportunity was lost.

After analyzing the process of documentation, as well as the assignment of business transactions to the accounting registers, it would be worthwhile to develop documents that systematize information on the institution's expenditures and revenues. The initial entry of information begins with non-current assets. Thus, accountants would have a chance to check the information on budget and financial statements before their submission, i.e. to exercise prior control before the publication of reports on the website of the State Treasury Service of Ukraine. First, such an improvement would speed up the reporting of the State Treasury Service of Ukraine and reduce its workload. Secondly, for accountants of the budgetary institution, the risks of committing offenses would be reduced and non-compliance with budget legislation would be prevented. Thus, the use of such documents would allow to find omissions and inaccuracies in accounting, analyze them, find the reasons for their occurrence, which are not always related to the activities of accountants, which lays the groundwork for analyzing errors and eliminating them in the future. 
To ensure the rational use of resources, compliance with financial and budgetary discipline, the implementation of such management functions as accounting and control plays an important role. Improving the organization of inventory accounting, ensuring its control functions over the economic and financial activities of budgetary organizations is the basis for compliance with accounting in budgetary institutions. High quality accounting information creates the conditions for effective implementation of all management functions [6, p.152].

One of the problems is the formal nature of the inventory process in budgetary institutions. In the practice of enterprises, institutions and organizations, it is established that most managers of budgetary institutions are not interested in the accounting results of the inventory, but in documenting this process. That is, the accuracy of the documentation prevails over the accounting information carried by the inventory process, which, in our opinion, in today's reality is incorrect and is accompanied by negative consequences. The inventory is designed to provide an opportunity to assess the existing property status of the budgetary institution and identify inaccuracies and errors of officials that were made in carrying out business activities in budgetary institutions. That is why it would be worthwhile to develop internal documents and more widely use information technology in inventory, which will speed up the process and eliminate formalization, increasing its role in practice.

It should be noted that one of the problematic aspects that exists in the accounting of non-current assets of budgetary institutions is the difficulty in determining the type of repair (capital / current) for an ordinary accountant. Only the commission appointed by the decision of the head of the institution can, on the basis of its acquired knowledge

\section{Список бібліографічних посилань}

1. Бюджетний кодекс України від 08 липня 2010 р. № 2456-VI (ред. станом на 01.01.2020 р.). URL : https://zakon.rada.gov.ua/laws/show/2456-17 (дата звернення: 08.06.2020).

2. Писаренко Т. М. Особливості організації обліку у бюджетних установах. Економічні науки. Серія: Облік і фінанси. 2013. Вип. 10(2). С. 193-202. URL : http://nbuv.gov.ua/ UJRN/ecnof_2013_10\%282\%29_27 (дата звернення: 08.06.2020).

3. Про затвердження Методичних рекомендацій з бухгалтерського обліку для суб'єктів державного сектору : Наказ Міністерства фінансів України від 23 січня 2015 р. № 11. URL : https://zakon.rada.gov.ua/rada/show/v0011201-15 (дата звернення: 06.06.2020). and professional skills, determine whether the repairs were carried out at the expense of capital expenditures or at the expense of current repairs. That is, upon receipt of the accountant of the budgetary institution of any primary documents for the repair, only in some cases the type of repair (capital / current) is indicated. As you know, if the overhaul of non-current tangible assets, the value of such an object increases. Currently, the situation is such that all this causes an additional burden on the accountant, ie the accountant does not have the technical specialty to make an independent decision, to which costs they should be attributed. That is why it would be worthwhile to divide the primary documents into two categories: in terms of capital and current expenditures.

Conclusions. Accounting in budgetary institutions does not lose its relevance regardless of economic processes and global trends. Efficient and rational use of available stateowned property and resources will always be the key to successful economic reforms and social achievements. This can be achieved only by improving the existing system of budget accounting and bringing it to world standards.

Non-current assets are the largest part of assets in budgetary institutions, so the study of their accounting and providing their own proposals for their elimination will always be a priority for domestic and foreign scholars. The abandonment of the value criterion in determining the ownership of the asset will improve not only the accounting processes, but also ensure the quality of the planning of expenditure indicators for the coming years.

The introduction of the proposed recommendations for improving accounting in budgetary institutions will accelerate the process of implementing international accounting standards in domestic accounting practice.

\section{References}

1. Byudzhetnyy kodeks Ukrainy vid 08 lyp. 2010 roku \# 2456-VI [Budget Code of Ukraine from July 8, 2010 No. 2456VI]. (2010). Retrieved from: https://zakon.rada.gov.ua/laws/ show/2456-17 [in Ukranian].

2. Pysarenko, T.M. (2013) Osoblyvosti orhanizatsii obliku $\mathrm{u}$ biudzhetnykh ustanovakh [Features of the organization of accounting in budgetary institutions]. Ekonomichni nauky - Economic sciences, 10(2), pp. 193-202. Retrieved from: http://nbuv.gov.ua/UJRN/ecnof_2013_10\%282\%29_27 [In Ukranian]. 
4. Про затвердження національних положень (стандартів) бухгалтерського обліку в державному секторі 121 "Основні засоби" : Наказ Міністерства фінансів України від 12 жовтня 2010 р. № 1202. URL : https://zakon.rada.gov.ua/laws/ show/z1017-10\#n18 (дата звернення: 08.05.2020).

5. Про затвердження Порядку складання, розгляду, затвердження та основних вимог до виконання кошторисів бюджетних установ : Постанова Кабінету Міністрів України від 28 лютого 2002 р. № 228. URL : https://zakon.rada.gov.ua/ laws/show/228-2002-n (дата звернення: 15.04.2020).

6. Свірко С. В. Організація бухгалтерського обліку у бюджетних установах : навчальний посібник. Київ : КНЕУ, 2006. 380 c

7. Ballas A., Panagiotou V., Tzovas Ch. Accounting Choices for Tangible Assets: A Study of Greek Firms. SPOUDAI Journal of Economics and Business. 2014. Vol. 64. Issue 4. P. 18-38.

8. Georgescu Cristina E. Comparative Analysis Regarding Fixed Assets: IAS/IFRS - Romanian Regulations. Ovidius University Annals, Economic Sciences Series. 2014. Vol. XIV. Issue 1. P. 606-611.

9. Mihalcea Mihaela M., Hada Izabela D., Litan Cristina S. Accounting policies on fixed assets and their influence on the financial performance of the economic entity. Annals Economy Series. 2018. Vol. SPECIAL. P. 209-215.

10. Paliu Popa L. Legislative accounting and fiscal nonconformities. Annals - Economy Series. 2016. Vol. 2 (Special). P. 38-40. URL : https://www.utgjiu.ro/revista/ec/pdf/2016Special\%20ECOTREND\%20Vol\%202/08_popapaliu.pdf.

11. Sarkisyan Zh. Models of Institutional Organization of Budgetary Control in Foreign Countries. Journal of Advanced Research in Law and Economics.. 2018. [S.l.]. V. 9. №. 1. P. 287-294. https://doi.org/10.14505//jarle.v9.1(31). 34.
3. Pro zatverdzhennia Metodychnykh rekomendatsii z bukhhalterskoho obliku dlia subiektiv derzhavnoho sektoru: Nakaz Ministerstva Finansiv Ukrainy vid 23 sich. 2015 roku \# 11 [On approval of Methodical recommendations on accounting for public sector entities: Order of the Ministry of Finance of Ukraine from January 23, 2015, No. 11]. (2010). Retrieved from: https://zakon.rada.gov.ua/rada/show/v0011201-15 [In Ukranian].

4. Pro zatverdzhennia natsionalnykh polozhen (standartiv) bukhhalterskoho obliku $v$ derzhavnomu sektori 121 "Osnovn zasoby": Nakaz Ministerstva finansiv Ukrainy vid 12 zhovt. 2010 roku \# 1202 [About the statement of national provisions (standards) of accounting in the public sector 121 "Fixed assets": Order of the Ministry of Finance of Ukraine from October 12, 2010, No. 1202]. Retrieved from: https://zakon.rada.gov.ua/ laws/show/z1017-10\#n18 [In Ukranian].

5. Pro zatverdzhennia Poriadku skladannia, rozghliadu, zatverdzhennia ta osnovnykh vymoh do vykonannia koshtorysiv biudzhetnykh ustanov: Postanova Kabinetu Ministriv Ukrainy vid 28 liut. 2002 roku \# 228. [About the statement of the Order of drawing up, consideration, the statement and the basic requirements to performance of estimates of budgetary institutions: Resolution of the Cabinet of Ministers of Ukraine from February 28, 2002, No. 228]. (2002). Retrieved from: https: //zakon.rada.gov.ua/laws/show/228-2002-n [In Ukranian].

6. Svirko, S.V. (2006). Orhanizatsiia bukhhalterskoho obliku u biudzhetnykh ustanovakh: navch. posibn [Organization of accounting in budgetary institutions]. Kyiv: KNEU [in Ukranian].

7. Ballas, A., Panagiotou, V. \& Tzovas, Ch. (2014). Accounting choices for tangible assets: A Study of Greek Firms. SPOUDAI Journal of Economics and Business, vol. 64, issue 4, pp. 18-38 [In English].

8. Georgescu, Cristina E. (2014). Comparative Analysis Regarding Fixed Assets: IAS/IFRS - Romanian Regulations. Ovidius University Annals, Economic Sciences Series, vol. XIV, issue 1, pp. 606-611 [In English].

9. Mihalcea, Mihaela M., Hada, Izabela D. \& Litan, Cristina S. (2018). Accounting policies on fixed assets and their influence on the financial performance of the economic entity. Annals - Economy Series, vol. Special, pp. 209-215 [In English].

10. Paliu Popa L. (2016). Legislative accounting and fiscal non-conformities. Annals - Economy Series, vol. 2 (Special), pp. 38-40. Retrieved from: https://www.utgjiu.ro/revista/ec/pdf / 2016-Special\%20ECOTREND\%20Vol\%202/08 popapaliu.pdf [In English].

11. Sarkisyan, Zh. (2018). Models of Institutional Organization of Budgetary Control in Foreign Countries. Journal of Advanced Research in Law and Economics, [S.l.], v. 9, n. 1, pp. 287-294 [In English]. Doi: https://doi.org/10.14505// jarle.v9.1(31).34.

\section{Проданчук М. А., Бездушна Ю. С. Проблеми обліку необоротних активів у бюджетних інституціях та шляхи}

їх вирішення

Мета статmі - ідентифікувати проблемні аспекти обліку необоротних активів і запропонувати шляхи їх вирішення через застосування інформаційних технологій та документального супроводу.

Методика дослідження. Методичною основою дослідження є системний підхід до вивчення процесів відображення необоротних активів у бухгалтерському обліку бюджетних установ. Гносеологічний метод застосовано для уточнення та поглиблення змісту поняття «необоротні активи». Аналіз, синтез, індукція, дедукція, абстрагування, ідеалізація та узагальнення, як загальнонаукові методи пізнання, застосовано для розвитку вихідних положень теорії, методики та організації облікового відображення необоротних активів. Бібліографічний і бібліометричний види аналізу забезпечили виявлення тенденцій розвитку теорії та методики обліку, а також проблемних аспектів у частині необоротних активів. Метод формалізації дав можливість внести пропозиції щодо шляхів вирішення проблемних аспектів бухгалтерського обліку необоротних активів.

Результати дослідження. Виявлення проблемних аспектів в обліку необоротних активів бюджетних установ дало змогу запропонувати варіанти їх вирішення, що спрятиме поглибленню інформативності даних обліку і звітності, забезпечить їх точність, достовірність і зіставність. Удосконалення облікових аспектів відображення необоротних активів також сприятиме підвищенню ефективності внутрішнього контролю (у т.ч. інвентаризації), а отже, управлінню ними в бюджетних установах.

Елементи наукової новизни. Удосконалено теоретичні та практичні положення щодо облікового відображення необоротних активів бюджетних установ. Запропоновано шляхи покращення обліку та внутрішнього контролю необоротних активів для потріб управління в бюджетних установах.

Практична значущість. 3 метою приведення національної облікової системи до міжнародних стандартів та відповідно до потреб управління запропоновано удосконалювати відображення в обліку необоротних активів бюджетних установ через використання інформаційних технологій та документального супроводу. Бібліогр.: 11.

Ключові слова: необоротні активи; облік; звітність; основні засоби; інвентаризація; бюджетні установи; державний сектор. 
Проданчук Михайло Андрійович - доктор економічних наук, доцент, провідний науковий співробітник відділу обліку та оподаткування, Національний науковий центр «Інститут аграрної економіки» (03127, м. Київ, вул. Героїв Оборони, 10)

E-mail: prodanchukma@gmail.com

ORCID iD https://orcid.org/0000-0003-3504-4583

Бездушна Юлія Сергіївна - кандидат економічних наук, старший науковий співробітник, завідувач відділу обліку та оподаткування, Національний науковий центр «ннститут аграрної економіки» (03127, М. Київ, вул. Героїв Оборони, 10)

E-mail: bezdushna@vipo.biz.ua

ORCID iD https://orcid.org/0000-0002-5924-0805

Проданчук М. А., Бездушная Ю. С. Проблемы учёта необоротных активов в бюджетных институциях и пути их решения

Цель статьи - идентифицировать проблемные аспекты учета необоротных активов и предложить пути их решения путем применения информационных технологий и документального сопровождения.

Методика исследования. Методической основой исследования является системный подход к изучению процессов отражения необоротных активов в бухгалтерском учете бюджетных учреждений. Гносеологический метод использоваг для уточнения и углубления содержания понятия «внеоборотные активы». Анализ, синтез, индукция, дедукция, абстрагирование, идеализация и обобщение, как общенаучные методы познания, применены для развития исходных положений теории, методики и организации учетного отражения основных средств. Библиографический и библиометрический виды анализа обеспечили выявление тенденций развития теории и методики учета, а также проблемных аспектов в части основных средств. Метод формализации дал возможность внести предложения относительно путей решения проблемных аспектов бухгалтерского учета основных средств.

Результаты исследования. Выявление проблемных аспектов в учёте необоротных активов бюджетных учреждений позволило предложить варианты их решения, что будет способствовать углублению информативности данных учета и отчётности, обеспечит их точность, достоверность и сопоставимость. Совершенствование учетных аспектов отображения необоротных активов также будет способствовать повышению эффективности внутреннего контроля (в т.ч. инвентаризации), следовательно и управлению ими в бюджетных учреждениях.

Элементы научной новизны. Усовершенствованы теоретические и практические положения относительно учётного отображения необоротных активов бюджетных учреждений. Предложены пути улучшения учета и внутреннего контроля необоротных активов для нужд управления в бюджетных учреждениях.

Практическая значимость. С челью приведения национальной учетной системы к международным стандартам и в соответствии с потребностями управления предложено совершенствовать отображение в учёте необоротных активов бюджетных учреждений посредством использования информационных технологий и документального сопровождения. Библиогр.: 11.

Ключевые слова: внеоборотные активы; учёт; отчетность; основные средства; инвентаризация; бюджетные учреждения; государственный сектор.

Проданчук Михаил Андреевич - доктор экономических наук, доцент, ведущий научный сотрудник отдела учёта и налогообложения, Национальный научный центр «Институт аграрной экономики» (03127, г. Киев, ул. Героев Обороны, 10)

E-mail: prodanchukma@gmail.com

ORCID iD https://orcid.org/0000-0003-3504-4583

Бездушная Юлия Сергеевна - кандидат экономических наук, старший научный сотрудник, заведующая отделом учёта и налогообложения, Национальный научный центр «Институт аграрной экономики» (03127, Г. Киев, ул. Героев Обороны, 10)

E-mail: bezdushna@vipo.biz.ua

ORCID iD https://orcid.org/0000-0002-5924-0805

The article has been received 11.12.2020

Revision: 15.12.2020

Бібліографічний опис для цитування:

Prodanchuk M. A., Bezdushna Yu. S. Accounting for non-current assets in budgetary institutions: problems and solutions. Економіка АПК. 2020. № 12 . С. 22 - 28. https://doi.org/10.32317/2221-1055.202012022

Prodanchuk, M.A. \& Bezdushna, Yu.S. (2020). Accounting for non-current assets in budgetary institutions: problems and solutions. Ekonomika APK, 12, pp. $22-28$ [In English]. https://doi.org/10.32317/2221-1055.202012022 